\title{
Impact of critical success factors on successful technology implementation in Consumer Pack- aged Goods (CPG) supply chain
}

\author{
Ranjan Arora $^{\mathrm{a}^{*}}$, Abid Haleem ${ }^{\mathrm{b}}$ and Jamal A. Farooquie ${ }^{\mathrm{c}}$
}

${ }^{a}$ Aligarh Muslim University, Aligarh, Uttar Pradesh 202002, India

${ }^{b}$ Jamia Millia Islamia, New Delhi 110025, India

${ }^{c}$ Aligarh Muslim University, Aligarh, Uttar Pradesh 202002, India

\section{H R O N I C L E}

Article history:

Received: October 1, 2016

Received in revised format: November 16, 2016

Accepted: February 15, 2017

Available online:

February 15, 2017

\section{Keywords:}

Critical Success Factors (CSFs)

Supply Chain Management (SCM)

Consumer Packaged Goods

(CPG)

Exploratory Factor Analysis

(EFA)

Technology Implementation

\section{A B S T R A C T}

\begin{abstract}
The purpose of this study is to identify and analyze the impact of critical success factors (CSFs) impacting technology implementation in Consumer Packaged Goods (CPG) supply chain. The study has used existing literature to identify CSFs and then questionnaire-based survey and Exploratory Factor Analysis (EFA) to group CSFs. The paper has revealed that "Inter-Organizational", "Organizational", "CPG Sector Specific", "Human" and "Program Management" CSFs impact successful technology implementation in CPG supply chain. The paper fills the gap in existing literature by studying the impact of CSFs on successful technology implementation in CPG supply chain and providing guidance to practitioners working in CPG sector.
\end{abstract}

\section{Introduction}

CPG organizations need to provide wide range of options along with keeping abreast with the changing consumer needs and business scenario (Noorani et al., 2007). CPG organizations are under constant pressure to launch efficient and effective new product innovations (Noorani et al., 2007; Søndergaard et al., 2007) and promotional campaigns (Tang et al., 2014). In order to be competitive in this global environment, CPG organizations have realized the importance of supply chain (Zokaei et al., 2007; Sahay et al., 2002). Organizations need to invest in enabling infrastructure (Marien, 2000) and technology (Sahay et al., 2003) to realize supply chain vision into reality. Technology has become an enabler for an organization's supply chain instead of a weapon of competition (Hong, 2002). Disappointing

* Corresponding author.

E-mail address: ranjan.arora@gmail.com (R. Arora) 
outcomes of technology investment pose a serious challenge (Kim et al., 2006) along with slow adoption of technology in supply chain (Johnston et al., 2000). Hence successful implementation of technology has been a matter of significant discussion.Thus, it is essential for organizations to focus on CSFs and understand the impact of these CSFs on successful technology implementation. The literature on supply chain technology implementation, didn't discuss CSFs pertaining to CPG sector. This has motivated the authors to study CSFs affecting successful technology implementation in CPG supply chain.

The objectives of this paper are to

- identify CSFs from existing literature

- study the impact of CSF's on successful technology implementation in CPG supply chain

- recognize societal and technological impact

- $\quad$ suggest future research directions

\section{Research Methodology}

\subsection{Identification of CSFs for successful technology implementation in CPG supply chain}

CSFs for successful technology implementation in CPG supply chain have been identified through extensive literature review. Most of the earlier research has not specifically focused on CPG sector and the research has been broad based. It has been assumed that CSFs identified from ERP implementation and other industries will be applicable for technology implementation in CPG supply chain. In this study, a total of 24 CSFs have been identified which includes 4 CSFs pertaining to CPG sector. The same is presented in Table 1.

\section{Table 1}

Critical Success Factors (CSFs)

\begin{tabular}{|c|c|c|}
\hline S.No & Critical Success Factors (CSFs) & References \\
\hline 1 & Top Management Support (C1) & $\begin{array}{l}\text { Annamalai et al., 2013; Singh 2013; Ngai et al., 2008; Stanley et al., 2006; Bhatti } \\
\text { 2005; Favilla et al., 2005; Haleem et al., } 2012\end{array}$ \\
\hline 2 & Organization's willingness and commitment (C2) & Hammant, 1997; Damien, 2005; Kumar et al., 2016 \\
\hline 3 & $\begin{array}{l}\text { Alignment between Information Technology (IT) and } \\
\text { business objectives (C3) }\end{array}$ & Upadhyay et al., 2011; Chang, 2006; Done et al., 2011; Kolbusak-McGee 1998 \\
\hline 4 & Proper IT investment justifications (C4) & Sandhu et al., 2012; Upadhyay et al., 2011 \\
\hline 5 & Change management initiatives (C5) & Bozarth, 2006; Saini et al., 2013; Sandhu et al., 2012; Hoffer et al., 1998 \\
\hline 6 & Trust between supply chain partners (C6) & $\begin{array}{l}\text { Paul, 2003; Laeequddin et al., 2012; Anbanandam et al., 2011; Stanley et al., 2008; } \\
\text { Norris et al., 2001; Jharkharia et al., 2005; Buxmann et al., 2004; Olorunniwo et } \\
\text { al., 2010; Borade et al., 2010; Sahay et al., 2003; Pomponi et al., } 2015\end{array}$ \\
\hline 7 & $\begin{array}{l}\text { Cooperation and commitment of supply chain partners } \\
\text { (C7) }\end{array}$ & Fynes et al. , 2005; Flynn et al., 2010; Park et al.,2001 \\
\hline 8 & Cultural alignment among partners (C8) & Thakkar et al., 2008; Gunasekaran et al., 2013 \\
\hline 9 & $\begin{array}{l}\text { Investment in IT infrastructure by supply chain part- } \\
\text { ners (C9) }\end{array}$ & $\begin{array}{l}\text { Kannabiran et al., 2012; Somuyiwa et al., 2011; Toussea-Oulai, 2007; Thakkar et } \\
\text { al., } 2008\end{array}$ \\
\hline 10 & $\begin{array}{l}\text { Dynamic information sharing model with supply chain } \\
\text { partners }(\mathrm{C} 10)\end{array}$ & Stanley, 2008; Norris et al., 2001; Jharkharia et al., 2005 \\
\hline 11 & Effective governance and program management (C11) & Fawcett et al., 2006; Mandal et al., 2003 \\
\hline 12 & Effective risk mitigation strategy $(\mathrm{C} 12)$ & Mandal et al., 2003; Giunipero et al., 2005 \\
\hline 13 & Preparedness for business process reengineering $(\mathrm{C} 13)$ & Ngai et al., 2008; Garg et al., 2013 \\
\hline 14 & $\begin{array}{l}\text { Involvement of Employees/ end-users during imple- } \\
\text { mentation stage (C14) }\end{array}$ & $\begin{array}{l}\text { Bingi et al., 1999; Holland et al., 1999; Sandhu et al., 2012; Shaaban et al., 2014; } \\
\text { McMullan 1996; Upadhyay et al., } 2011\end{array}$ \\
\hline 15 & Proper training of end-users $(\mathrm{C} 15)$ & Thakkar et al., 2008; Kapp et al., 2001; Ngai et al. ,2008 \\
\hline 16 & $\begin{array}{l}\text { Assurance of job security for employees post IT imple- } \\
\text { mentation (C16) }\end{array}$ & Garg et al., 2013; Daneva, 2007 \\
\hline 17 & Competence of the project team $(\mathrm{C} 17)$ & Upadhyay et al., 2011, Stratman et al., 2002; Hashim, 2007 \\
\hline 18 & Proper information security (C18) & Kannabiran et al., 2012; Borade et al., 2010 \\
\hline 19 & Selecting the right supply chain package (C19) & McMullan 1996; Annamalai et al., 2013; Sahay et al., 2003 \\
\hline 20 & Data Management (C20) & Adebanjo et al., 2000; Corney, 2002 \\
\hline 21 & Gaining competitive advantage (C21) & $\begin{array}{l}\text { Altıntas et al., 2010; Noorani et al., 2007; Steele et al., 1994; Korotkov et al., 2013; } \\
\text { Tang et al., 2014; Shimp, 2003; Sabir, et al., } 2014\end{array}$ \\
\hline 22 & Peer Pressure (C22) & Kannabiran, 2012; Cragg et al., 2002 \\
\hline 23 & $\begin{array}{l}\text { Involvement of Marketing team during planning phase } \\
\text { (C23) }\end{array}$ & Inman et al.,2009; Korotkov et al., 2013; Rose, 2009 \\
\hline 24 & Focus on Consumer (C24) & Zokaei et al., 2007; Lowson, 2001 \\
\hline
\end{tabular}




\subsection{Survey}

A questionnaire based survey has been used to establish relationship between identified CSF's and successful technology implementation. The questionnaire was first sent to 25 respondents (Academicians working as Supply chain experts and Supply Chain \& IT executives of CPG organizations) to ensure that questions were appropriate and easy to understand \& respond. Based on the feedback received from 25 respondents, 3 questions were dropped and 10 questions were refined.

Questionnaire was then sent to 300 professionals working with CPG organizations at different levels of managerial responsibility. The questions were asked on a five-point Likert scale. On this scale 1 and 5 correspond to "very low importance" and "very high importance" respectively. 210 professionals shared responses but 10 responses were dropped because of incompleteness.

\subsection{Data Analysis}

Cronbach's coefficient $(\alpha)$ was calculated to test the reliability and internal consistency of the responses. The value of $\alpha$ in this study was found to be 0.816 which is considered acceptable (Cronbach, 1951). Skewness and kurtosis are used to validate the data for normality (Bo et al., 2015). The values of more than \pm 1 are often taken to indicate non-normality (Hair, 2014). Table 2 presents basic statistics including min, max, standard deviation, Skewness and Kurtosis. The values were well within desirable levels and principle component analysis needs to be used to extract the main factors.

Table 2

Basic statistics

\begin{tabular}{|c|c|c|c|c|c|c|c|c|c|}
\hline & \multirow{2}{*}{$\frac{\mathrm{N}}{\text { Statistic }}$} & \multirow{2}{*}{$\frac{\text { Minimum }}{\text { Statistic }}$} & \multirow{2}{*}{$\begin{array}{c}\text { Maximum } \\
\text { Statistic }\end{array}$} & \multirow{2}{*}{$\begin{array}{c}\text { Mean } \\
\text { Statistic }\end{array}$} & \multirow{2}{*}{$\frac{\text { Std. Deviation }}{\text { Statistic }}$} & \multicolumn{2}{|c|}{ Skewness } & \multicolumn{2}{|c|}{ Kurtosis } \\
\hline & & & & & & Statistic & Std. Error & Statistic & Std. Error \\
\hline $\mathrm{C} 1$ & 200 & 1 & 5 & 3.56 & .986 & -.296 & .172 & -.028 & .342 \\
\hline $\mathrm{C} 2$ & 200 & 1 & 5 & 3.45 & .971 & -.121 & .172 & -.020 & .342 \\
\hline $\mathrm{C} 3$ & 200 & 1 & 5 & 3.72 & 1.004 & -.485 & .172 & -.198 & .342 \\
\hline $\mathrm{C} 4$ & 200 & 1 & 5 & 3.66 & .948 & -.165 & .172 & -.420 & .342 \\
\hline C5 & 200 & 1 & 5 & 3.66 & 1.025 & -.312 & .172 & -.340 & .342 \\
\hline C6 & 200 & 1 & 5 & 3.41 & .840 & -.124 & .172 & .102 & .342 \\
\hline C7 & 200 & 1 & 5 & 3.35 & .842 & -.011 & .172 & -.174 & .342 \\
\hline $\mathrm{C} 8$ & 200 & 1 & 5 & 3.24 & .770 & .036 & .172 & .171 & .342 \\
\hline C9 & 200 & 1 & 5 & 3.26 & .814 & .063 & .172 & -.058 & .342 \\
\hline $\mathrm{C} 10$ & 200 & 1 & 5 & 3.30 & .796 & -.230 & .172 & .128 & .342 \\
\hline C11 & 200 & 1 & 5 & 3.23 & .779 & .227 & .172 & .025 & .342 \\
\hline $\mathrm{C} 12$ & 200 & 1 & 5 & 3.23 & .823 & .052 & .172 & .093 & .342 \\
\hline C13 & 200 & 1 & 5 & 3.23 & .788 & .191 & .172 & -.066 & .342 \\
\hline $\mathrm{C} 14$ & 200 & 1 & 5 & 2.88 & .954 & .138 & .172 & -.948 & .342 \\
\hline C15 & 200 & 1 & 5 & 3.10 & .894 & -.103 & .172 & -.408 & .342 \\
\hline $\mathrm{C} 16$ & 200 & 1 & 5 & 2.79 & .970 & .299 & .172 & -.521 & .342 \\
\hline C17 & 200 & 1 & 5 & 2.84 & .946 & .207 & .172 & -.884 & .342 \\
\hline $\mathrm{C} 18$ & 200 & 1 & 4 & 2.72 & .672 & -.112 & .172 & -.108 & .342 \\
\hline C19 & 200 & 1 & 4 & 2.62 & .719 & -.037 & .172 & -.252 & .342 \\
\hline $\mathrm{C} 20$ & 200 & 1 & 4 & 2.70 & .696 & -.318 & .172 & .082 & .342 \\
\hline $\mathrm{C} 21$ & 200 & 2 & 5 & 4.31 & .675 & -.764 & .172 & .670 & .342 \\
\hline $\mathrm{C} 22$ & 200 & 2 & 5 & 4.31 & .636 & -.598 & .172 & .549 & .342 \\
\hline $\mathrm{C} 23$ & 200 & 2 & 5 & 4.33 & .636 & -.660 & .172 & .592 & .342 \\
\hline $\mathrm{C} 24$ & 200 & 2 & 5 & 4.36 & .626 & -.695 & .172 & .735 & .342 \\
\hline
\end{tabular}

C1- C24: 24 CSFs

Further Exploratory Factor Analysis (EFA) was done to identify the underlying relationships between CSFs. Table 3 presents Kaiser-Meyer-Olkin (KMO) and Bartlett's test results. KMO is coming to 0.812 and results are statistically significant. 
Table 3

KMO and Bartlett's Test

Kaiser-Meyer-Olkin Measure of Sampling Adequacy

Bartlett's Test of Sphericity

\begin{tabular}{ll} 
& .812 \\
Approx. Chi-Square & $2.978 \mathrm{E} 3$ \\
Df & 276 \\
Sig. & .000 \\
\hline
\end{tabular}

We can see from Scree plot (Fig. 1) and Total variance explained (Table 4) that first six factors represent most influential items. The total variance explained by 6 components is $75.8 \%$. Table 5 represents the results of principal component analysis after Promax rotation.

\section{Table 4}

Total variance explained

\begin{tabular}{|c|c|c|c|c|c|c|c|}
\hline \multirow[b]{2}{*}{ Component } & \multicolumn{3}{|c|}{ Initial Eigenvalues } & \multicolumn{3}{|c|}{ Extraction Sums of Squared Loadings } & \multirow{2}{*}{$\begin{array}{c}\begin{array}{c}\text { Rotation Sums of } \\
\text { Squared Loadings }\end{array} \\
\text { Total }\end{array}$} \\
\hline & Total & $\%$ of Variance & Cumulative \% & Total & $\%$ of Variance & Cumulative \% & \\
\hline 1 & 5.346 & 22.274 & 22.274 & 5.346 & 22.274 & 22.274 & 4.235 \\
\hline 2 & 3.822 & 15.926 & 38.201 & 3.822 & 15.926 & 38.201 & 4.374 \\
\hline 3 & 2.718 & 11.326 & 49.526 & 2.718 & 11.326 & 49.526 & 3.294 \\
\hline 4 & 2.599 & 10.830 & 60.356 & 2.599 & 10.830 & 60.356 & 3.062 \\
\hline 5 & 1.974 & 8.225 & 68.581 & 1.974 & 8.225 & 68.581 & 2.560 \\
\hline 6 & 1.736 & 7.232 & 75.813 & 1.736 & 7.232 & 75.813 & 2.787 \\
\hline 7 & .618 & 2.574 & 78.387 & & & & \\
\hline 8 & .557 & 2.320 & 80.707 & & & & \\
\hline 9 & .471 & 1.963 & 82.670 & & & & \\
\hline 10 & .403 & 1.681 & 84.351 & & & & \\
\hline 11 & .388 & 1.617 & 85.968 & & & & \\
\hline 12 & .379 & 1.577 & 87.545 & & & & \\
\hline 13 & .375 & 1.563 & 89.107 & & & & \\
\hline 14 & .344 & 1.432 & 90.539 & & & & \\
\hline 15 & .325 & 1.354 & 91.893 & & & & \\
\hline 16 & .289 & 1.206 & 93.099 & & & & \\
\hline 17 & .274 & 1.142 & 94.241 & & & & \\
\hline 18 & .247 & 1.030 & 95.272 & & & & \\
\hline 19 & .230 & .959 & 96.231 & & & & \\
\hline 20 & .224 & .933 & 97.164 & & & & \\
\hline 21 & .208 & .868 & 98.033 & & & & \\
\hline 22 & .191 & .795 & 98.827 & & & & \\
\hline 23 & .145 & .605 & 99.432 & & & & \\
\hline 24 & .136 & .568 & 100.000 & & & & \\
\hline
\end{tabular}

Extraction Method: Principal Component Analysis.

a. When components are correlated, sums of squared loadings cannot be added to obtain a total variance.

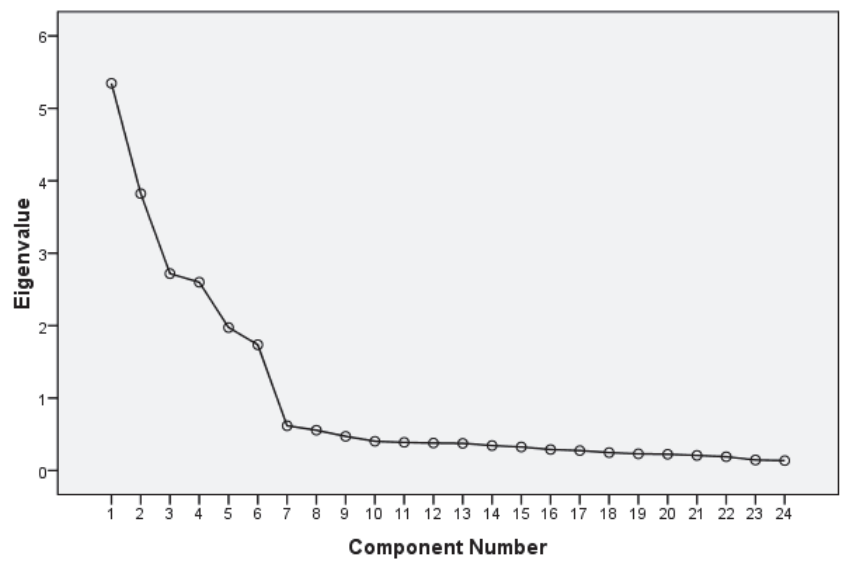

Fig. 1. Scree Plot 
Table 5

Pattern Matrix (Principal Component Analysis after Promax rotation)

\begin{tabular}{|c|c|c|c|c|c|c|}
\hline & \multicolumn{6}{|c|}{ Component } \\
\hline & 1 & 2 & 3 & 4 & 5 & 6 \\
\hline $\mathrm{C} 1$ & .865 & & & & & \\
\hline $\mathrm{C} 2$ & .889 & & & & & \\
\hline $\mathrm{C} 3$ & .832 & & & & & \\
\hline $\mathrm{C} 4$ & .901 & & & & & \\
\hline $\mathrm{C} 5$ & .914 & & & & & \\
\hline C6 & & .870 & & & & \\
\hline $\mathrm{C} 7$ & & .849 & & & & \\
\hline $\mathrm{C} 8$ & & .895 & & & & \\
\hline $\mathrm{C} 9$ & & .898 & & & & \\
\hline $\mathrm{C} 10$ & & .879 & & & & \\
\hline C11 & & & & & & .912 \\
\hline $\mathrm{C} 12$ & & & & & & .907 \\
\hline C13 & & & & & & .857 \\
\hline $\mathrm{C} 14$ & & & & .860 & & \\
\hline C 15 & & & & .794 & & \\
\hline C16 & & & & .844 & & \\
\hline C17 & & & & .805 & & \\
\hline C18 & & & & & .902 & \\
\hline C19 & & & & & .897 & \\
\hline $\mathrm{C} 20$ & & & & & .865 & \\
\hline $\mathrm{C} 21$ & & & .807 & & & \\
\hline $\mathrm{C} 22$ & & & .894 & & & \\
\hline $\mathrm{C} 23$ & & & .867 & & & \\
\hline $\mathrm{C} 24$ & & & .749 & & & \\
\hline
\end{tabular}

Extraction Method: Principal Component Analysis.

Rotation converged in 6 iterations.

Based on this, 24 CSFs have been divided into 6 components as depicted in Figure 2. The first CSF extracted from Factor Analysis is "Organizational" and includes 'Top Management Support', 'Organization's willingness and commitment', 'Alignment between IT and business objectives', 'Proper IT investment justifications' and 'Change management initiatives'. The second CSF "Inter-Organizational" extracted from Factor Analysis pertains to supply chain partner parameters, and includes 'Trust', 'Cooperation and commitment', 'Cultural alignment', 'Investment in IT infrastructure' and 'Dynamic information sharing model' between supply chain partners. The third CSF "Program Management" extracted from Factor Analysis includes 'Effective governance and program management', 'Effective risk mitigation strategy' and 'Preparedness for business process reengineering'. The fourth CSF " Human" pertains to factors involving employees and includes 'Involvement of Employees/ endusers during implementation stage', ' Proper training of end-users', 'Assurance of job security for employees post IT implementation' and 'Competence of the project team'. The fifth CSF "Technology" extracted from Factor Analysis includes 'Proper information security', 'Selecting the right supply chain package' and 'Data Management'. The sixth component " CPG Sector Specific” pertains to CPG related parameters and includes 'Gaining competitive advantage', 'Peer Pressure', 'Involvement of Marketing team during planning phase' and 'Focus on Consumer'. Finally, the relationship of these 6 CSFs on successful technology implementation needs to be identified. 
- Top Management Support

- Organization's willingness and commitment

- Alignment between IT and business objectives

- Proper IT investment justifications

- Change management initiatives

- Trust between supply chain partners

- Cooperation and commitment of supply chain partners

- Cultural alignment among partners

- Investment in IT infrastructure by supply chain partners

- Dynamic information sharing model with supply chain partners

- Involvement of Employees/ end-users during implementation stage

- Proper training of end-users

- Assurance of job security for employees post IT implementation

- Competence of the project team
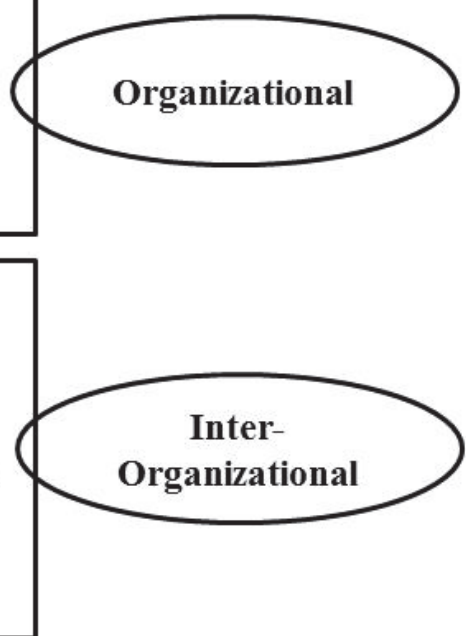

- Proper information security

- Selecting the right supply chain package

- Data Management

Human

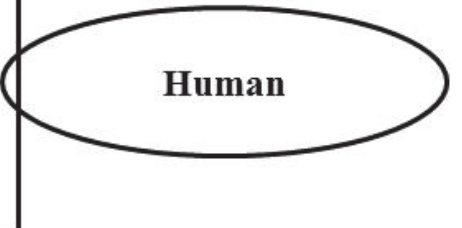

Technology

Program Management

- Effective risk mitigation strategy

- Preparedness for business process reengineering

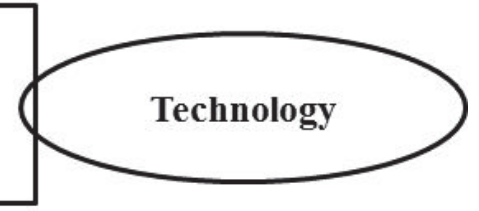

- Effective governance and program management

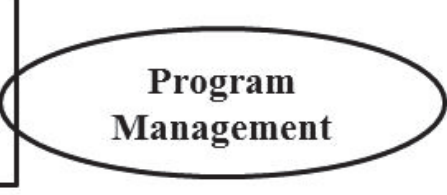

- Gaining competitive advantage

- Peer Pressure

- Involvement of Marketing team during planning phase

- Focus on Consumer

Fig. 2. Critical Success Factors (CSFs) post Factor Analysis

\section{Results \& Discussion}

\subsection{Result}

In this section, we identify the relationship of these 6 components namely "Inter-Organizational" (I), "Organizational" (O), "CPG Sector Specific" (C), "Human" (H), "Technology" (T) and "Program Management" (P) on successful technology implementation in CPG supply chain. Based on the survey and statistical test conducted, it is suggested that 
Implementation Success $=.301+.304(\mathrm{I})+.299(\mathrm{O})+.179(\mathrm{C})+.177(\mathrm{H})+.137(\mathrm{P})$

The model suggests that I, O, C, P and $\mathrm{H}$ have significant impact on technology implementation at 95\% significant level and T doesn't have significant impact on technology implementation. The details of our finding, is depicted in table 6 and summary of the results in Table 7.

Table 6

Regression Analysis

\begin{tabular}{|c|c|c|c|c|c|c|c|c|c|c|}
\hline \multirow[b]{2}{*}{ Model } & \multicolumn{2}{|c|}{$\begin{array}{l}\text { Unstandardized Coeffi- } \\
\text { cients }\end{array}$} & \multirow{2}{*}{$\begin{array}{l}\text { Standardized Coef- } \\
\text { ficients } \\
\text { Beta }\end{array}$} & \multirow[b]{2}{*}{$\mathrm{t}$} & \multirow[b]{2}{*}{ Sig. } & \multicolumn{3}{|c|}{ Correlations } & \multicolumn{2}{|c|}{ Collinearity Statistics } \\
\hline & B & Std. Error & & & & Zero-order & Partial & Part & Tolerance & VIF \\
\hline (Constant) & .301 & .412 & & .729 & .467 & & & & & \\
\hline IMEAN & .283 & .057 & .304 & 4.929 & .000 & .443 & .334 & .284 & .873 & 1.145 \\
\hline OMEAN & .228 & .046 & .299 & 4.984 & .000 & .386 & .337 & .287 & .921 & 1.086 \\
\hline CMEAN & .222 & .074 & .179 & 2.989 & .003 & .278 & .210 & .172 & .926 & 1.080 \\
\hline HMEAN & .146 & .049 & .177 & 2.962 & .003 & .240 & .208 & .171 & .933 & 1.072 \\
\hline PMEAN & .147 & .063 & .137 & 2.326 & .021 & .098 & .165 & .134 & 951 & 1.052 \\
\hline
\end{tabular}

Dependent Variable: Implementation Success MEAN

Table 7

Impact of Critical Success Factors (CSFs) on successful technology implementation

"Organizational" CSF's will have positive impact on successful implemen- Accept tation of technology in CPG supply chain

"Inter-Organizational" CSF's will have positive impact on successful imple- Accept mentation of technology in CPG supply chain

"Human" CSF's will have positive impact on successful implementation of Accept technology in CPG supply chain

"Technology" CSF's will have positive impact on successful implementa- Reject tion of technology in CPG supply chain

"Program Management" CSF's will have positive impact on successful im- Accept plementation of technology in CPG supply chain

"CPG Sector Specific" CSF's will have positive impact on successful im- Accept plementation of technology in CPG supply chain

\subsection{Discussion on findings}

From the results obtained, it is found that "Organizational", "Inter-Organizational", "Human" and "Program Management" CSFs will have positive impact on successful technology implementation in CPG supply chain. This is well supported by previous studies done in other industries which states that successful technology implementation requires a committed organization (Hammant, 1997) along with the support from top management (Kotzab et al., 2003; Favilla et al., 2005; Jharkharia et al., 2005) and a sustainable change management system (Bozarth, 2006). Trust between supply chain partners is essential for a successful technology implementation (Laeequddin et al., 2012; Anbanandam et al., 2011; Kotzab et al., 2003). Supply chain technology implementation seem to succeed or fail on the degree of resource sharing (information, knowledge \& skills) along with the partner's ability to use these resources effectively in the changing environments (Stanley, 2008; Jharkharia et al., 2005). 
Employees play a major role in the implementation (Shaaban et al., 2014) along with expertise of implementation consultants (McMullan, 1996). Employees should understand the rationale for implementation (Garg et al., 2013) along with getting proper training. It is also important to have preparedness for Business Process Reengineering (Favilla et al., 2005) along with using a proven implementation methodology (Favilla et al., 2005), effective governance, program management \& risk-mitigation strategy during implementation (Hammant, 1997).

One of the major findings of this study is the positive impact of "CPG Sector Specific" CSF on successful technology implementation. The findings highlight that a) Gaining competitive advantage b) Peer Pressure c) Involvement of marketing team during planning phase and d) focus on Consumer, positively impacts technology implementation. The impact of this CSF has not been studied earlier and this is the first of its kind study which has focused on this CSF along with other CSFs.

The last finding of this study states that "Technology" CSF will not have significant positive impact on successful technology implementation in CPG supply chain. Though, the earlier studies in other sectors have emphasized that implementation success depends on choosing the right technology \& product for the organization (Annamalai et al., 2013) along with information security framework (Borade et al., 2010).

\section{Conclusion and Implication}

The main findings of this research in line with the stated objectives are

- 24 CSFs have been identified from existing literature and then grouped into 6 using factor analysis

- fills the gap in existing literature by focusing on CPG sector as the previous research work in this field lacked focus on CPG sector

- "Inter-Organizational" CSF has higher and more significant impact, followed by "Organizational", "CPG sector specific", "Human" and "Program Management" CSFs on successful technology implementation in CPG supply chain

- emphasized the positive impact of "CPG sector specific" CSF on successful technology implementation in CPG supply chain

- "Technology" CSF doesn't have a significant impact on successful technology implementation in CPG supply chain

The integrated approach suggested practitioners to concentrate on both softer aspects ("Organizational", "Inter-Organizational", "Human", and "Program Management") along with "CPG sector specific" CSF which will help in delivering enhanced outcomes and improved performance. It also provides guidance to managers by focusing on high priority CSFs "Inter-Organizational", "Organizational", "CPG sector specific" and "Human" (in order of priority from high to low).

The proposed study has some limitations which can be undertaken in future research. Structural Equation Modeling (SEM) can be applied to further test the validity of this model. This research has been done for CPG sector and similar research needs to be done for other sectors.

\section{References}

Adebanjo, D., \& Mann, R. (2000). Identifying problems in forecasting consumer demand in the fast moving consumer goods sector. Benchmarking: An International Journal, 7(3), 223-230.

Altıntas, H.M., Kılıc, S., Senol , G., \& Isin, B.F. (2010). Strategic objectives and competitive advantages of private label products. International Journal of Retail \& Distribution Management, 38(10), 773-788. 
Anbanandam, R., Banwet ,D.K., \& Shankar ,Ravi (2011). Evaluation of supply chain collaboration: a case of apparel retail industry in India. International Journal of Productivity and Performance Management, 60(2), 82-98.

Annamalai, C., \& Ramayah, T. (2013). Does the organizational culture act as a moderator in Indian enterprise resource planning (ERP) projects?. Journal of Manufacturing Technology Management, 24 (4), 555-587.

Bhatti, T.R. (Ed.) (2005). Critical success factors for the implementation of enterprise resource planning (ERP) empirical validation. Paper presented at The Second International Conference on Innovation in Information Technology (IIT05), Zayed University, College of Business, Dubai, UAE.

Bingi, P., Sharma, M.K., \& Godla, J. (1999). Critical issues affecting an ERP implementation. Information Systems Management, 16(2), 7-14.

Bo, X., Martin, S., \& Bo, X. (2015). A critical review of structural equation modeling applications in construction research. Automation in Construction, 49, 59-70.

Borade, B. A., \& Bansod, V. S. (2010). Study of vendor-managed inventory practices in Indian industries. Journal of Manufacturing Technology Management, 21(8), 1013-1038.

Bozarth, C. (2006). ERP implementation efforts at three firms. International Journal of Operations \& Production Management, 26(11), 1223-1239.

Buxmann, P., Von Ahsen, A., D1'az, L.M., \& Wolf, K. (2004). Usage and evaluation of supply chain management software - results of an empirical study in the European automotive industry. Information Systems Journal, 14(3), 295-309.

Chang, H.H. (2006). Technical and management perceptions of enterprise information system importance, implementation and benefits. Info Systems Journal, 16, 263-292.

Corney, D. (2002). Food bytes: intelligent systems in the food industry. British Food Industry, 104(10), 787-805.

Cronbach, L.J. (1951), Coefficient alpha and the internal structure of tests, Psychometrika, 16(3), 297334.

Cragg, P., \& King, M. (2002). IT alignment and firm performance in small manufacturing firms. The Journal of Strategic Information Systems, 11(2), 109-132.

Damien, P. (2005). Determinants of business-to-business e-commerce implementation and performance: a structural model. Supply Chain Management: An International Journal, 10(2), 96-113.

Daneva, M. (2007). Understanding success and failure profiles of ERP requirements engineering: an empirical study. Proceedings of the 33rd EUROMICRO Conference on Software Engineering and Advanced Applications, Luebeck, Germany, 28-31 August, 237-243.

Done, A., Voss, C., \& Rytter, N. (2011). Best practice interventions: short-term and long-term outcomes. The Journal of Operations Management, 29, 500-513.

Favilla, J., \& Fearne, A. (2005). Supply chain software implementations: getting it right. Supply Chain Management: An International Journal, 10(4), 241-243.

Flynn, B., Huo, B., \& Zhao, X. (2010). The impact of supply chain integration on performance: a contingency and configuration approach. Journal of Operations Management, 28(1), 58-71.

Fynes, B., de Burca, S., \& Voss, C. (2005). Supply chain relationship quality: the competitive environment and performance. International Journal of Production Research, 43(16).

Garg, P., \& Garg, A. (2013). An empirical study on critical failure factors for enterprise resource planning implementation in Indian retail sector. Business Process Management Journal, 19(3), 496514.

Giunipero, L.C., Denslow, D., \& Eltanatwy, R. (2005). Purchasing/supply chain management flexibility: moving to an entrepreneurial skill set. Industrial Marketing Management, 34(6), 602-613.

Gunasekaran, A., Patel, C., \& McGaughey, E. (2013). A framework for supply chain performance measurement. International Journal of Production Economics, 87(3), 333-47.

Hair Jr, J. F., Hult, G. T. M., Ringle, C. \& Sarstedt, M. (2014). A Primer on Partial Least Squares Structural Equation Modeling (PLS-SEM), SAGE Publications. 
Haleem, A., Sushil, Q., Asim, M., \& Kumar, S. (2012). Analysis of critical success factors of worldclass manufacturing practices: an application of interpretative structural modelling and interpretative ranking process. Production Planning \& Control, 23(10-11), 722-734.

Hammant, J. (1997). Implementing a European supply chain strategy: turning vision into reality. Proceedings of the International Conference on Logistics and the Management of the Supply Chain, Sydney, Australia, AIMM/LMA/APICS/ AIPMM, 95-100.

Hashim, J. (2007). Information communication technology (ICT) adoption among SME owners in Malaysia. The International Journal of Business and Information, 2, 221-240.

Hoffer, J.A., George, J.F., \& Valacich, J.S. (1998). Modern System Analysis and Design. 2nd ed., Addison-Wesley, Reading, MA.

Holland, C.P., \& Light, B. (1999). A critical success factors model for ERP implementation. IEEE Software, 16, 30-36.

Hong, I.B. (2002). A new framework for interorganizational systems based on the linkage of participants' roles. Information \& Management, 39(4), 261-270.

Inman, J., Winer, R., \& Ferraro, R. (2009). The interplay among category characteristics, customer characteristics, and customer activities on in-store decision making. Journal of Marketing, 73(3), 19-29.

Jharkharia, S., \& Shankar, R. (2005). IT-enablement of supply chains: understanding the barriers. The Journal of Enterprise Information Management, 18(1), 11-27.

Johnston, R.B., \& Mak, H.C. (2000). An emerging vision of Internet-enabled supply chain electronic commerce. International Journal of Electronic Commerce, 4(4), 43-59.

Kannabiran, G., \& Dharmalingam, P. (2012). Enablers and inhibitors of advanced information technologies adoption by SMEs. Journal of Enterprise Information Management, 25(2), 186-209.

Kapp, K.M., Latham, W.F., \& Ford-Latham, H. (2001). Integrated Learning for ERP Success: A Learning Requirements. St Lucie CRC Press, New York, NY.

Kim, D., Cavusgil, S. T., \& Calantone, R. J. (2006). Information system innovations and supply chain management: Channel relationships and firm performance. Journal of the Academy of Marketing Science, 34, 40-54.

Kolbusak-McGee, M. (1998). Better supply chains - study identifies best practices to help ensure implementation. Information Week, October 12.

Korotkov, N., Occhiocupo, N., \& Simkin, L. (2013). Simulated test marketing in emerging markets: the need to re-think. Marketing Intelligence \& Planning, 31(7), 807-822.

Kotzab, H., Skjoldager, N., \& Vinum, T. (2003). The development and empirical validation of an ebased supply chain strategy optimization model. Industrial Management \& Data Systems, 103(5), 347-360.

Kumar, S., Luthra, S., Govindan, K., Kumar, N., \& Haleem, A. (2016). Barriers in green lean six sigma product development process: an ISM approach. Production Planning \& Control, 27(7-8), 604-620.

Laeequddin , M. , Sahay, B.S, Sahay, V., \& Waheed, A. K. (2012). Trust building in supply chain partners relationship: an integrated conceptual model. Journal of Management Development, 31(6), 550-564.

Lowson, H. R. (2001). Retail operational strategies in complex supply chains. The International Journal of Logistics Management, 12(1), 97-111.

Mandal, P., \& Gunasekaran, A. (2003). Issues in implementing ERP: a case study. European Journal of Operational Research, 146, 274-83.

Marien, E.J. (2000). The four supply chain enablers. Supply Chain Management Review, 4, 60.

McMullan, A. (1996). Supply chain management practices in Asia Pacific today. International Journal of Physical Distribution \& Logistics Management, 26(10), 79-95.

Ngai, E.W.T., Law, C.C.H., \& Wat, F.K.T. (2008). Examining the critical success factors in the adoption of enterprise resource planning. Computers in Industry, 59, 548-564.

Noorani, S.H., \& Setty, K.M.B. (2007). Three steps for successful implementation of sales portals in CPG companies. International Journal of Retail \& Distribution Management, 35(9), 746-749. 
Norris, G., Hurley, J.R., Hartley, K.M., \& Dunleavy, J.R. (2001). E-business and ERP: Transforming the Enterprise, John Wiley, London

Olorunniwo, F.O., \& Li, X. (2010). Information sharing and collaboration practices in reverse Logistics. Supply Chain Management: An International Journal, 15(6), 454-462.

Park, S.H., \& Ungson, G.R. (2001). Inter-firm rivalry and managerial complexity: a conceptual framework of alliance failure. Organization Science, 12(1), 37-53.

Paul, L.G. (2003). Suspicious minds: collaboration among trading partners can unlock great value. Mistrust is a barrier. Here are six ways to build confidence. $C I O, 16(7), 74-82$.

Pomponi, F., Fratocchi, L., \& Tafuri, S.R. (2015). Trust development and horizontal collaboration in logistics: a theory based evolutionary framework. Supply Chain Management: An International Journal, 20(1), 83-97.

Rose, L. (2009). Relationships in fast moving consumer goods markets. European Journal of Marketing, 45 (4), 651-672.

Sabir, B. L., Farooquie, A. J. \& Ullah, A. (2014). Economic discounting and stocking of perishables: A simulation based approach for wholesalers. Global Journal of Management and Business Research: A Administration and Management, 14(3), 71-80.

Sahay, B.S., Cavale, V., \& Mohan, R. (2003). The Indian supply chain architecture. Supply Chain Management - An International Journal, 8(2), 93-106.

Sahay, B.S., \& Gupta, A.K. (2002). Supply chain management in Indian FMCG sector. Productivity, 42(4), 564-573.

Saini, S., Nigam, S. and Misra, C. S. (2013). Identifying success factors for implementation of ERP at Indian SMEs. Journal of Modelling in Management, 8 (1), 103-122.

Sandhu, M., \& Ajmal, M. (2012). The adoption of ICT in project-based and traditional organizations. Journal of Enterprise Information Management, 25(1), 7-27.

Shaaban, M. S., \& Ali H. A. (2014). Critical success factors for total productive manufacturing (TPM) deployment at Egyptian FMCG companies. Journal of Manufacturing Technology Management, 25(3), 393-414.

Shimp, T.A. (2003), Advertising, Promotion, and Supplemental Aspects of Integrated Marketing Communications, 6th ed., Thomson South-Western, Boston, MA.

Singh, K. R. (2013). Prioritizing the factors for coordinated supply chain using analytic hierarchy process (AHP). Measuring Business Excellence, 17(1), 80-98.

Somuyiwa, A., \& Adebayo, T. (2011). Analysis of information and communication technologies (ICT) usage on logistics activities of manufacturing companies in Southwestern Nigeria. Journal of Emerging Trends in Economics and Management Sciences, 2, 68-74.

Søndergaard, A. H., \& Harmsen, H. (2007). Using market information in product development. Journal of Consumer Marketing, 24(4), 194-201.

Stanley,E. F., Gregory, M.M., \& McCarter, W. M. (2008). Benefits, barriers, and bridges to effective supply chain management. Supply Chain Management: An International Journal, 13(1), 35-48.

Stanley, E. F., Jeffrey, A. Ogden, G., Magnan, M., \& Cooper, M. B. (2006). Organizational commitment and governance for supply chain success. International Journal of Physical Distribution \& Logistics Management, 36(1), 22-35.

Steele, W., \& Plunkett, K. (1994). Finished stock: The piggy in the middle. Logistics Information Management, 7(6), 16-22.

Stratman, J.K., \& Roth, A.V. (2002). Enterprise resource planning (ERP) competence constructs: twostage multi-item scale development and validation. Decision Sciences, 33, 601.

Tang, C.Y., Wang, M.Y., \& Huang, Y.H. (2014). Optimal promotional strategy for intra-category cross-selling. British Food Journal, 116(1), 80-90.

Thakkar, J., Thakkar, A., \& Deshmukh, G.S. (2008). Interpretive structural modeling (ISM) of ITenablers for Indian manufacturing SMEs. Information Management \& Computer Security, 16(2), $113-136$

Toussea-Oulai, A. (2007). Information technology transfer: problems facing African developing nations. International Journal of Human Computer Interaction, 3, 79-93. 
Upadhyay, P., Jahanyan, S., \& Dan, K. P. (2011). Factors influencing ERP implementation in Indian manufacturing organizations. Journal of Enterprise Information Management, 24(2), 130-145.

Zokaei, K., \& Hines, P. (2007). Achieving consumer focus in supply chains. International Journal of Physical Distribution \& Logistics Management, 37(3), 223-247.

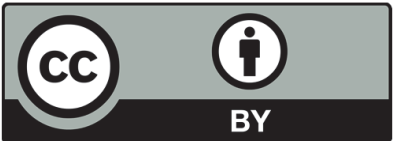

(C) 2017 by the authors; licensee Growing Science, Canada. This is an open access article distributed under the terms and conditions of the Creative Commons Attribution (CC-BY) license (http://creativecommons.org/licenses/by/4.0/). 